\title{
Ecosystem services in spatial planning
}

\author{
Małgorzata Kowalczyk, Paweł Sudra \\ Institute of Spatial Management and Housing, \\ 45 Targowa St., 03-728 Warsaw, Poland \\ mk@igpim.pl, pawel.sudra@igpim.pl
}

\begin{abstract}
Although the ecosystem services concept is very popular in recent years, its use in spatial planning is limited. The aim of this paper is to describe current problems of ecosystem services application in the spatial planning process. There are two aspects of research; the first is associated with the definitions and classifications of ecosystem services while the second is related to the use of the concept in supporting the decision-making processes in spatial planning. The first part of the paper discusses the definition and existing classifications system of ecosystem services and its usefulness for spatial planning. The second part is of more legal nature and is related to the spatial planning procedure. Proposals how to fit the ecosystem services concept into the planning process are presented in this part.
\end{abstract}

Keywords: ecosystem services, spatial planning, strategic environmental assessment, financial impact assessment.

\section{Introduction}

Mutual relation between the humans and environment is an important topic of the geographical and biological research. The significance of natural environment for human well-being seems to be obvious. From the beginning of humanity the natural resources and environmental conditions strongly affected human life - settlement decisions were based on natural conditions, i.e. elevation, water availability, agriculture and food production possibilities, etc. In this context it is not necessary to underline the significance of ecosystems and natural resources for the human life.

Due to its increasing popularity, the concept of ecosystem services and its implementation is widely discussed by the academics, politician, governments and many other groups of interest. Clark and Dickson (2003) have defined ecosystem services as a 'cornerstone of sustainability science' for its focus on the interaction between nature and society. As the recent research shows there are some possibilities to incorporate the concept of ecosystem services into the projections of the effects of policy choices (Carpenter et al. 2009; Tallis, Polasky 2009) however, the use of ecosystem services concept in real-life decision making processes is still limited (Geneletti 2012).

From the spatial planning point of view it seems to be important to understand what kind of natural benefits people derive from nature and which of them are crucial and most valuable, and how people value them. According to the European Commission (1997) spatial planning aims at "creating a more rational organization of land uses and the linkages between them, to balance demands for development with the need to protect the environment and to achieve social and economic develop- 
ment objectives". Therefore, there is a strict relationship between land and natural resources use, which can be identified as ecosystem services to some extent, and the spatial planning resulting in space organization. One may say that spatial planning is a crucial decision-making process of natural resources use for human welfare and well-being. It is a process which encompasses economic, environmental and social aspects of widely understood development. Moreover, the spatial planning is one of the tools of sustainable development implementation because of the involved territorial dimension of all mentioned above aspects of human development process (economic growth, social equity and ecological balance).

This paper aims at describing current problems related to ecosystem services concept and its application in the spatial planning process. The first part is focused on the problems related to definitions and classification of ecosystem services, and relation between spatial scale and ecosystem services identification. The second illustrates the spatial planning procedure in Poland and various documents, i.e. local plan of spatial development and SEA, into which ecosystem services concept could be integrated.

\section{Definition and classification of ecosystem services}

One of the first definitions of 'ecosystem services' was formulated by Costanza et al. (1997), who states that the ecosystem services are "the benefits the human populations derive, directly or indirectly, from the ecosystem functions." According to another frequently cited definition, they are "benefits people obtain from ecosystems" (MEA 2005). Wallace (2007) has defined and classified ecosystem services as benefits which are a vital link in the decisions concerning management of natural resources. There are many others definitions of ecosystem services which appear quite often in the literature, and some of them are presented in Table 1. It is worth mentioning that there is no one widely accepted definition of ecosystem services which would encompass all important features of ecosystem services.

Table 1. Selected definitions of ecosystem services

\begin{tabular}{|l|l|}
\hline Author & Ecosystem services definition \\
\hline de Groot et al. 2002 & $\begin{array}{l}\text { "the capacity of natural processes and components to provide goods and } \\
\text { services that satisfy human needs, directly or indirectly" }\end{array}$ \\
\hline Kremen, 2005 & "the set of ecosystem functions that is useful to humans" \\
\hline Jenkins et al. 2010 & $\begin{array}{l}\text { "a collective term for the goods and services produced by ecosystems that } \\
\text { benefit humankind" }\end{array}$ \\
\hline
\end{tabular}

Generally, one may say that the ecosystem services are benefits that natural environment provides to the society and economics. However, as Table 1 shows, the definitions of ecosystem services are somewhat unclear. On the one hand the ecosystem services are defined as processes or functions, on the other they are defined as goods or products. The main problem with the definition unclearness is the relation between the process and the product, and the possibility that the product will be an effect of the process. To avoid this and, in consequence, the double counting of ecosystem services, Boyd and Banzhaf (2007) define final ecosystem services as "the 
components of nature, directly enjoyed, consumed or used to yield human well-being", and propose to omit two of four types of ecosystem services mentioned in MEA (2005), i.e. the regulating and supporting services. However, such a simplification of the concept could be useful for marketing or educational purposes, but it does not convey the complexity of natural phenomena (Kowalczyk, Kulczyk 2012).

While continuing the discussion on the definition of term 'ecosystem services', with an attempt to resolve it, one should not ignore the generally accepted definition of 'services'. Service can be defined as 'the action of helping or doing work for someone' or 'a system satisfying a public need such as transport, communications, or utilities such as electricity and water' (Oxford Dictionary').

From the economic point of view, services can also be paraphrased in terms of their four key characteristics (Wolak, Kalafatis, Harris 1998). The first one is intangibility - this means that services are non-material. Furthermore, services can be sold or owned by somebody, but they cannot be handed over by the service provider to the service consumer. The second one is perishability - this means that the services cannot be stored for a future use. As mentioned above, the services have little or no tangible components and, therefore, they have to be produced and consumed during the same period of time. In other words, if the service consumer does not request and consume the service during a defined period of time, the service cannot be performed for him. The third characteristic of services is inseparability - this means that the service provider is indispensable for the service delivery. In many cases the service delivery is automatic. Additionally, the service consumer is inseparable from the service delivery because he/she is involved in it from the moment of requesting it up to the moment of consuming the benefits. The fourth feature is heterogeneity - this means that the services can be modified depending on the service consumer or a new situation. The participation of the customer in the service delivery process results in that a customer has the opportunity to get the services modified according to the specific requirements. Each service is unique. It is one-time generated, rendered and consumed and can never be exactly repeated as far as the point in time, location, circumstances, conditions, current configurations are concerned.

According to the above, it seems to be justified to define ecosystem services rather as processes than products which are material and can be stored.

Some of ecosystem services listed in various classifications (Costanza et. al. 1997, De Groot et al. 2002, MEA 2005, Farber et al. 2006, Wallace 2007) do not have the key features of services. Therefore, the question comes up whether they should be defined as ecosystem services? As example may serve some of the provisioning services presented in Table 2, food and fibre in particular, which are strictly related to crops and timber.

\footnotetext{
1 http://www.oxforddictionaries.com (access date: 08.01.2015).
} 
Table 2. Types of ecosystem services in the Millennium Ecosystem Assessment (2005) (partial)

\begin{tabular}{|c|c|}
\hline Type of service & Example of service \\
\hline Provisioning services & $\begin{array}{l}\text { Food } \\
\text { Fibre } \\
\text { Genetic resources } \\
\text { Bio-chemicals, natural medicines } \\
\text { Ornamental resources } \\
\text { Fresh water }\end{array}$ \\
\hline Regulating services & $\begin{array}{l}\text { Air quality regulation } \\
\text { Climate regulation } \\
\text { Water regulation } \\
\text { Erosion regulation } \\
\text { Disease regulation } \\
\text { Pest regulation } \\
\text { Pollination }\end{array}$ \\
\hline Cultural services & $\begin{array}{l}\text { Cultural diversity } \\
\text { Spiritual and religious values } \\
\text { Recreation and ecotourism } \\
\text { Aesthetic values } \\
\text { Knowledge systems } \\
\text { Educational values }\end{array}$ \\
\hline Supporting services & $\begin{array}{l}\text { Soil formation } \\
\text { Photosynthesis } \\
\text { Primary production } \\
\text { Nutrient cycling } \\
\text { Water cycling }\end{array}$ \\
\hline
\end{tabular}

Source: Millennium Ecosystem Assessment, 2005.

As mentioned above, there are many classifications of ecosystem services. According to Wallace (2007) the main problem of the most classifications of ecosystem services consists in confusing the means (processes for achieving services) and ends (services themselves). Therefore, there is a need to define what is understood under the term 'ecosystem services'. As the Millennium Ecosystem Assessment (2005) states: "the full range of benefits reflecting human well-being from ecosystems must be represented in any effective typology of ecosystem services."

Some problems related to the typology of ecosystem services have been pointed out by Kowalczyk and Kulczyk (2012) who made research focused on tourism and recreation. As they underline, the tourism and recreation are recognized by the most popular classifications of ecosystem services. In most of them tourism and recreation is associated with the cultural services. However, it seems to be impossible to separate this kind of human activity from another types of ecosystem services.

Table 3 presents differences in the approach to the tourism in the selected classifications of ecosystem services. 
Table 3. Tourism and Recreation within different classifications of ecosystem services

\begin{tabular}{|c|c|c|c|c|}
\hline Classification & $\begin{array}{l}\text { Position of tourism } \\
\text { and recreation }\end{array}$ & $\begin{array}{l}\text { Recognition } \\
\text { of material } \\
\text { aspects }\end{array}$ & $\begin{array}{l}\text { Recognition of } \\
\text { non-material } \\
\text { aspects }\end{array}$ & Notes \\
\hline Costanza et al. ${ }^{2}$ & $\begin{array}{l}\text { One of } 17 \text { main } \\
\text { categories }\end{array}$ & yes & no & $\begin{array}{l}\text { Focus on eco-tourism and } \\
\text { outdoor recreation. }\end{array}$ \\
\hline $\begin{array}{l}\text { De Groot, Wilson, } \\
\text { Boumans }{ }^{3}\end{array}$ & $\begin{array}{l}\text { One of } 23 \text { ecosystem } \\
\text { function (recognized as } \\
\text { information function) }\end{array}$ & yes & yes & $\begin{array}{l}\text { Applies function }+ \text { process } \\
=\text { services and goods. } \\
\text { Classification of func- } \\
\text { tions, but only examples } \\
\text { of services provided. }\end{array}$ \\
\hline $\begin{array}{l}\text { Millennium } \\
\text { Ecosystem } \\
\text { Assessment }^{4}\end{array}$ & $\begin{array}{l}\text { One of } 4 \text { subgroups } \\
\text { of cultural ecosystem } \\
\text { services }\end{array}$ & no & yes & \\
\hline Wallace $^{5}$ & $\begin{array}{l}\text { One of } 6 \text { subgroups of } \\
\text { socio-cultural fulfilment } \\
\text { category }\end{array}$ & no & yes & \\
\hline Boyd and Banzhaf 6 & One of 6 benefits & yes & no & $\begin{array}{l}\text { Recreation as a benefit, } \\
\text { not as a service }\end{array}$ \\
\hline $\mathrm{CICES}^{7}$ & $\begin{array}{l}\text { One of } 23 \text { service } \\
\text { groups (within intel- } \\
\text { lectual and experiential } \\
\text { service class) }\end{array}$ & yes & no & $\begin{array}{l}\text { Focus on the use of } \\
\text { resources (direct and } \\
\text { indirect) }\end{array}$ \\
\hline
\end{tabular}

Source: Kowalczyk, Kulczyk 2012.

According to Costanza (2008), it is recommended to use various classifications of ecosystem services depending on the scope of research. Different divisions are needed for different subjects, with detail level increasing proportionally to the scale of research (Kowalczyk, Kulczyk 2012). Geneletti (2012) pointed out that the selection of key ecosystem services, which are relevant to the specific decision problems addressed by the spatial plan, and to the characteristics of the area is one of four challenges to the implementation of ecosystem services into land use planning.

\section{Ecosystem services and spatial planning}

Spatial planning refers to the methods used by the public sector, mostly national or local governments, to influence the distribution of people and activities in geographical space. Spatial planning is simultaneously a scientific discipline, an administrative technique and a strategic policy, being

\footnotetext{
2 R. Costanza et al., The value of the world's ecosystem services... op. cit., p. 254.

3 De Groot, Wilson, Boumans, A typology for the classification ... op. cit., p. 396.

${ }^{4}$ Millennium Ecosystem Assessment, Ecosystems... op. cit., p. 120.

5 K.J. Wallace, Classification of ecosystem services... op. cit. p. 241.

6 J. Boyd., S. Banzhaf, What are ecosystem services?..., op. cit., p. 623.

7 R. Haines-Young, M.Potchin, Common International Classification of Ecosystem Service...op.cit, p. 6.
} 
directly related to spatial management and territorial development. The planning takes place at various administrative levels, including local (municipal), regional, state, national and even international levels. Currently we perceive it as a set of methods to achieve sustainable development by linking ecological, economic and social aspects. It has several major roles which include, but are not limited to, creation of spatial order (shaping of landscape), ensuring high quality of living for the citizens, rationalization of land usage, protection of public goods and harmonization of interests of various socio-economic entities.

Usually to achieve these goals a spatial plan (spatial development plan) is established by the responsible authorities. Spatial plans may come in two distinct forms. A structure plan or master plan is typical for the higher levels of administration (national, regional) but can be made also at the level of municipality. It sets some strategic directions for development of the area (jurisdiction). Another form of plan is what we might call an "outline scheme" explicitly showing planned land use, infrastructures etc. Typically, a plan of this type is a local zoning plan or, in other words, a land use plan. This type of planning take place less frequently at the higher levels of administration, but this depends on the country.

One of the most important aspects of spatial planning is the environmental dimension and its relation with sustainable development. This is where the ecosystem services assessment might potentially come in. Spatial development plans can be seen as tools serving environmental conservation. Local zoning plans have a special role in this respect. Zoning, as such, serves the protection of ecologically rich areas - a term that defines areas which are excluded from development, serving as open spaces, recreation areas, aeration corridors, ecological corridors and buffer zones (e.g. city parks and other areas of urban greenery). Apart from zoning, in the spatial plans some supplementary regulations on the protection of environment are set, although many of them are derived from the external regulations. An example of such supplementary regulation might be a protective zone surrounding a groundwater source - a buffer restricting urbanization to a certain distance from the source. Another example is the ban on building on a slope where landslides occur. Last but not least, a spatial plan may set some spatial indicators for their respective territory which are obligatory for the new development to comply with. This might be a maximum percentage of built-up area on the plot, or a minimum percentage of "biologically active" area on the plot.

There are at least three main problems related to the application of ecosystem services in the land use planning, which can be defined as ' $3 \mathrm{M}$ ':

1. 'multiscale',

2. 'multiuser'

3. 'multiservice'

The first one - 'multiscale' - results from the fact that ecosystem services are provided and used at different spatial scales. Moreover, it is based on administrative units, whereas the environmental processes occur within the natural units (i.e. water basins, catchments) and extend beyond the administrative boundaries. One of the problems related to spatial scales is that a land use plan focuses on geographically bounded area, however, the provision and use of ecosystem services may take place within much broader area than the one limited with the boundaries of the plan. Therefore, the differences between the area that is being planned and the area that is being affected in terms of ecosystem services are resulting in difficulties of predicting the effects of implementation of a spatial plan (Geneletti 2012).

The other problem related to the spatial scale consists in identification and signification of ecosystem services depending on the planning tiers (national, regional, local). This problem can be 
illustrated by the role of forests and green spaces or just tree functions. At the national and even international level the crucial functions of forests and green spaces include climate regulation, carbon sequestration and reduction of greenhouse effect and timber production. At the regional tier the ecosystem services provided by green spaces are related to the protection against flood, ecological corridors, cultural landscape and timber production (similar at the national level). However, at the local level and in the urban planning the significance of green spaces and its functions are quite different. Ecosystem services of urban greenery areas are related to recreation, aesthetic values, acoustic protection and air-quality regulation. While at the national and regional level the statistical analyses of available resources play the crucial role (e.g. total timber harvest in the region), when moving down to the local scale and to the municipal areas, the regulatory services are still essential (e.g. green belts in cities supporting biodiversity and providing a function of aeration corridors), but the cultural values, which are much more subjective and related to human perception, start counting (e.g. well-shaped trees as a means to make public spaces more attractive).

The second problem with integration of ecosystem services into the land use planning is associated with the 'multiuser' aspect. The ecosystem services assessment serves to document the values the people assign to the ecosystems, and to evaluate benefits derived from nature (Costanza et al. 1997, De Groot et al. 2002, Chee 2004, Farber et al. 2006, Wallace 2007). One of most important features of the ecosystem services concept is that it links environment with its users, which means that services without demand do not exist (Kowalczyk, Kulczyk 2012). Therefore, one may say that the concept has an anthropocentric dimension. From the spatial planning point of view, involvement of various stakeholders in the planning process seems to be crucial. Land use planning should resolve the conflicts between different groups of beneficiaries competing for the use of natural resources.

It is difficult to identify and describe the demand related to ecosystem services because of the number of participants and groups of interest having different preferences as to the use of the environment. One group of stakeholders may prefer to conserve the natural environment in a certain area, whilst the others would prefer to use natural resources in a different way, i.e. for construction or for industry. Therefore, there is a need for detailed social research, in order to to describe which services and to what extent are crucial.

The third problem is associated with the 'multiservice' aspect which relates to the use of ecosystem services for land use planning in terms of identification and evaluation of the distribution of multiple ecosystem services, and it is connected to some extent with both previous problems. In other words, one ecosystem can provide different services and they can change depending on the territorial range. The significance of ecosystem services can change depending on the service consumer, which means there is a need to elaborate different scenarios for ecosystem services use.

Land use plan and spatial policies may affect the relative mix of ecosystem services within a region or municipality by trading off the increase in one service with relative decrease in another one (Geneletti 2012). Therefore, there is a need to identify ecosystem services and to indicate the crucial ones for a particular area. It can be done by analysing multiple ecosystem functions in different scenarios of spatial development. However, a huge amount of data is needed and the process of analysis can complicate the spatial planning process. 


\section{Ecosystem services assessment in local spatial planning}

In this part we analyse how the ecosystem services assessment could be implemented into the local planning in Poland. The scope of research focuses on the elaboration procedures for the land use plans and their three accompanying and obligatory documents: ecophysiographic study, strategic environmental assessment, financial impact assessment.

Certain solutions proposed further herein are related to the potential incorporation of the ecosystem services assessment in the spatial planning procedures on local level. Polish spatial planning system is referred to as an example. Therefore, basic information about this system has to be made available to a reader who might be unfamiliar with it.

In the Polish spatial planning system the decision-making is nowadays bound specifically to the local planning. In 1999 a major territorial administrative reform was implemented. The fundamental local level of administration, that is a gmina (municipality or commune), has been maintained in the total number of 2479 (as of 1 January 2013). However, 49 middle-sized voivodships were replaced by 16 big voivodships - regional administrative units better representing the historical regions or provinces of Poland. In addition, a middle level of territorial administration was introduced, a powiat, in the total number of 379 (as of 1 January 2013).

The 1994 Act on Spatial Management ${ }^{8}$ and, consequently, the 2003 Spatial Planning and Management Act $^{9}$ introduced the spatial planning procedures which reflected the new roles of self-governments and the changes in territorial administrative division in Poland. The major spatial development policies, problem areas, protective zones, communication and infrastructural interlinks and public purpose investments are determined in the National Spatial Development Concept ${ }^{10}(K P Z K)$ and in the Voivodship Spatial Development Plan ${ }^{11}(P Z P W)$ for each of the 16 voivodships. However, it is at the local level of municipality, where the planning actually takes place, including zoning of the area, real estate management, infrastructure planning, nature conservation and historical heritage protection regulations, setting development indicators for urban areas. The authorities of powiats have actually no role in the spatial planning system.

Responsibility for local planning rests with the municipality authorities, and it is the mayor who is legally responsible for the preparation of spatial development plans. The municipal council is entitled to approve or reject the final project of the plan after it undergoes a complex consultation procedure. There are two types of land use plans related to the local tier:

- Study of Land Use Conditions and Directions ${ }^{12}$ (SUiKZP) is an obligatory 'master plan' for the entire jurisdiction of municipality, which has not direct legal impact on the spatial management of the area, however, it puts some obligations in respect of the local zoning plans;

- Local Plan of Spatial Development ${ }^{13}(M P Z P)$ is facultative, however, with some exceptions, when it is obligatory. It is legally binding zoning plan for a specific area.

\footnotetext{
8 Ustawa o zagospodarowaniu przestrzennym z dnia 7 lipca 1994 r. (Dz. U. Nr 89, poz.415).

9 Ustawa o planowaniu i zagospodarowaniu przestrzennym z dnia 27 marca 2003 r. (Dz. U. Nr 80, poz. 717).

10 Koncepcja Przestrzennego Zagospodarowania Kraju.

11 Plan zagospodarowania województwa.

12 Studium uwarunkowań i kierunków zagospodarowania przestrzennego.

13 Miejscowy plan zagospodarowania przestrzennego.
} 
As of 31 December 2012, almost all municipalities have had a valid SUiKZP or they have been preparing or reviewing it. According to the Central Statistical Office ${ }^{14}$ the coverage of area of Poland with the local plans of spatial development (MPZP's) has been equal to about $27.9 \%$.

The actual spatial planning process at the local level is related specifically to the preparation of the draft of a spatial development plan, whether it is a 'master plan', such as SUiKZP, or a zoning plan, such as MPZP. Zoning is the major task of local planning since it defines the planned or legally admissible land use for a particular area. As stated above, the mayor of municipality is responsible for elaborating the draft of a spatial development plan. This process is always associated with demands of different groups of interest. Apart from the local government, these groups include local citizens, industry, real estate developers, ecologists and some others. Therefore, alternative development scenarios of spatial development plan will be considered to meet the needs of stakeholders involved into planning process, with trade-offs and following the rules of sustainable development.

As mentioned before, regarding the 'multiuser' problem, various stakeholders get different profits from the natural environment and they value it differently. Those profits are ecosystem services. For instance, in the case of a biologically rich area, e.g. an old forest, located in the urban surroundings, the ecologists would value its biodiversity and would be keen to protect it as a natural reserve, the local citizens might appreciate its suitability for recreation and influence on human health conditions, aiming to transform it into a city park, whereas the real estate developers would appreciate environmental assets, though they would press on transforming the open area into a built-up zone. For such reasons, the evaluation of ecosystem services might be an important part of the public participation process in spatial planning. The statutory public participation procedures in the Polish spatial planning system include primarily the opportunity to submit applications and requests to the project of the plan. However, non-statutory public participation methods might be also used, including public discussions, workshops, on-line consultations or even public participation with the use of interactive geographic information system tools ${ }^{15}$. Thus, the particular stakeholders may express their opinions on the alternative development scenarios.

The alternative development scenarios for a particular area can be seen in a slightly different manner, more tied to their economic implications. From this perspective, each development scenario is associated with alternative costs of performing or avoiding actions related to the environment, as well as with the costs of environmental compensation of the actions that have been undertaken or aborted. What might be applied here is the methodology of valuing the environment using the cost-benefits analysis (CBA), costs of substitution, regeneration or avoided loss. An example of this approach would be an assessment of the costs of building flood embankments or storage reservoirs in place of natural swamps. Both of these allow to prevent floods. The retention of flooding water in a swamp is a service delivered by the ecosystem of this area as a sort of natural regulating service. If the swamp is dried up it might have to be substituted with some technical (anthropogenic) constructions to protect surrounding human settlements from the flood impact. The ecosystem service which was of value for the local society that might be related to the monetary value of estates and utilities protected against flood, needs to be replaced with a construction which must be built and maintained, resulting in substantial financial costs. Another issue is that if we damage or destroy an ecosystem (e.g. a swamp), we get rid of a variety of other services it delivers.

14 Planowanie Przestrzenne w Gminach (PP-1), Główny Urząd Statystyczny, 2013.

15 An interesting article related to this subject is: Brown G., Montag J.M., Lyon K., 2012, "Public participation GIS: A method for identifying ecosystem services", Society \& Natural Resources, 25(7): 633-651. 
One of the most crucial documents concerning the role of environment in the spatial planning process is the ecophysiographic study. It is an obligatory diagnostic document that has to be prepared along with the project of both types of local land use plans. The ecophysiographic study shall be based on thorough examination of environmental conditions in the study area. The document presents diagnosis of the state and functioning of the environment and its components, reflecting the suitability of the natural environment for the planned development. It can be said that the ecosystem services reflect the potential of the environment and its components for the use by people and for the development. Therefore, they shall be taken into account in the diagnostic phase of the spatial planning process. Identification and evaluation of ecosystem services, including an attempt to their pricing, might help to determine whether the current land use is appropriate for particular area. In other words, it can be used for examination of land use efficiency and of development sustainability.

The obligation to prepare the ecophysiographic study for spatial development plans is imposed by the Environmental Protection Act (2001) ${ }^{16}$ and the ordinance of the Minister of Environment ${ }^{17}$ following this act. It is worth to mentioned that well done ecophysiographic study is a superb input for the preparation of the strategic environmental assessment of the plan (SEA).

The Strategic Environmental Assessment (SEA), similarly to the ecophysiographic study, is an environmentally-oriented document associated with spatial development plans. It is also mandatory for both types of spatial development plans. While ecophysiographic study has a diagnostic role, the strategic environmental assessment is a kind of prognostic study. In general, SEA is a type of study suited for predicting environmental effects of plans or programmes e.g. on land use, transport, energy, waste or agriculture. According to OECD (2006), SEA refers to a range of analytical and participatory approaches that aim to integrate environmental consideration into policies, plans and programmes and evaluate the interlinkages with economic and social consideration. One of the key objectives of SEA consists in supporting development policies and plans by assessing the environmental impacts that are likely to result from their execution (Geneletti 2012). The legal framework for making SEA's on European level is set by the European SEA Directive (2001/42/EC) ${ }^{18}$. According to the Polish law, the Act on Dissemination of Environmental Information, Public Participation in Environmental Protection and Environmental Impact Assessments (2008) ${ }^{19}$ to be precise, preparation of the strategic environmental assessments is obligatory for spatial development plans at all levels of administration, for regional development strategies, as well as for the sector-specific policies, strategies, plans and programmes.

According to the above-mentioned act, the strategic environmental assessment for the land use plans identifies and evaluates the state of environment, its changes, potential problems and forecast impact of the draft on the biodiversity, humans, animals, plants, water, air, land surface, landscape, climate, natural resources, monuments of culture, and their interdependencies. Therefore, preparation of SEA shall encompass various components of the natural environment, where each of them reflects a set of ecosystem services. If it is predicted that the environment will be affected by the actions proposed in the spatial development plan, the ecosystem services delivered in the study area will be also affected. Typically, in the case of development, the effect will be degradation of

\footnotetext{
16 Ustawa z dnia 27 kwietnia 2001 r. Prawo ochrony środowiska (Dz.U. 2001 nr 62 poz. 627).

17 Rozporządzenie Ministra Środowiska z dnia 9 września 2002 r. w sprawie opracowań ekofizjograficznych (Dz.U. 2002 nr 155 poz. 1298).

18 DIRECTIVE 2001/42/EC OF THE EUROPEAN PARLIAMENT AND OF THE COUNCIL of 27 June 2001 on the assessment of the effects of certain plans and programmes on the environment.

19 Ustawa z dnia 3 października 2008 r. o udostępnianiu informacji o środowisku i jego ochronie, udziale społeczeństwa w ochronie środowiska oraz o ocenach oddziaływania na środowisko (Dz. U. $2008 \mathrm{nr} 199$ poz. 1227).
} 
some components and functions of the environment and of the ecosystem services related to them. However, following the realization of the plan, certain ecosystem services may become reinforced or even some new ecosystem services in the study area might emerge. For instance, the actions of land restoration (ecological restoration) of a river valley, which has been previously dried up due to land amelioration, may lead to emergence of some new habitats and plant species. While this leads to an increase in biodiversity, people can also get some new services from the restored environment, such as useful plants (crops) or the cultural value of the landscape. Last but not least, it has to be stated that the SEA not only predicts environmental impacts of planned actions but also proposes solutions that will prevent, reduce or compensate negative impact of the plan on the environment.

Finally, the ecosystem services assessment could be linked with the Financial Impact Assessment (FIA) of a local plan of spatial development. According to the Spatial Planning and Management Act (2003) FIA is a mandatory prognostic document which has to be prepared along with the project of a local plan of spatial development (MPZP). The aforementioned Act does not precise any compulsory methodology for preparation of FIA and it does not require it to be in a specific form (descriptive, tabular, etc.). The Ordinance of the Minister of Infrastructure on the required contents of the Local Plan of Spatial Development (2003) ${ }^{20}$ does not do it either. It merely states that the financial impact assessment shall include a prognosis of the impact of the plan on incomes and expenses of the municipality. The most important sources of income are listed and include incomes from real property tax, property trade activities and the zoning change fee (a so-called "planning rent"). The crucial expenses of municipality which are listed in this case include expenses for zoning change compensations, property redemptions for public purpose investments and expenditures on technical infrastructure.

It seems that FIA for the local plan of spatial development (MPZP) could be seen in a broader perspective and could possibly include an assessment of the impact of the plan on the monetary value of ecosystem services. From this perspective FIA might include answers to such questions as: "What might be the impact of the planned land use change on the provision of natural resources and their prices?"; "What are the costs of environmental compensation of water balance change or soil erosion (ecological restoration)?"; "How do the changes in landscape would affect income from tourism?". This kind of the financial impact assessment would be related not only to the impact of the plan on the municipal budget, but would also be related to the social and environmental costs and benefits of planned actions. We can notice that FIA made in such manner would reflect the financial aspect of the strategic environmental assessment (SEA) of the local spatial development plan.

\section{Conclusions}

This paper has discussed how the ecosystem services could be integrated in spatial planning in Poland. Taking into account the findings it seems to be clear that the concept of ecosystem services has high applicability in the context of spatial planning. The ecosystem services concept may and shall be used in planning process to better suit the needs of the society and economy to the ecological conditions and possible environmental impacts of actions being taken.

20 Rozporządzenie Ministra Infrastruktury z dnia 26 sierpnia 2003 r. w sprawie wymaganego zakresu projektu miejscowego planu zagospodarowania przestrzennego (Dz. U. $2003 \mathrm{nr} 164$ poz. 1587). 
The starting point for land use planning is to see what kinds of profits are taken from the natural environment and how can the spatial management actions limit or boost these profits. Therefore, there is a need to agree on a coherent ecosystem services definition which is still ambiguous. The environmental valuation methods shall be better developed in order to describe precisely the assets of environment. Making these assets understandable and, whenever possible, expressed in monetary value is essential for both - the ecosystem services concept and sensible environmental management.

As the spatial planning in Poland forms a hierarchical system with the interdependencies between particular levels of hierarchy, there is a need to integrate the ecosystem services assessment at these different levels, especially at the local (municipal) level where most of the planning actions take place. However, it can be quite complicated because of some difficulties related to identification and valuation of ecosystem services in different geographical scales.

The identified challenges to the implementation of ecosystem services into spatial planning process are: 'multiscale', 'multiuser' and 'multiservice'. It is worth underlining the importance of the geographical scale of ecosystem services because land use planning and ecosystem services provisionrelate to different areal units - administrative and natural, respectively. Moreover, ecosystem services are provided and used in different geographical scales, and also can have varied significance depending on the scale.

The ecosystem services assessment may be a part of the actual planning process where alternative development scenarios are decided upon through zoning. The public shall be involved in the decision-making process for "go" or "not go" in case of planning development in environmentally sensitive and precious areas. Ecosystems in such areas often deliver significant services to the society, which cannot be squandered.

The recognition of environmental conditions for construction and development is important at the initial stage of the planning process, when the ecophysiographic study is prepared. The valuation and economic aspect of the ecosystem services assessment may be applied specifically in the strategic environmental assessment (SEA) and financial impact assessment (FIA). Currently FIA is related directly to the assessment of predicted incomes and expenses of the municipal budget that may result from the spatial development plan. However, in the case of integrating the ecosystem services assessment with SEA and binding this document with FIA, the latter could reflect the financial aspect of SEA - the economic impacts of the environmental changes for the whole municipality.

To sum up, integration of the ecosystem services into the spatial planning process seems to be very attractive idea that would serve the sustainable development on different levels of planning. However, some major obstacles will have to be challenged. These are: ambiguity of definitions of ecosystem services, variety of views on the environmental assets in the society, scale issues, multiplicity of the methods for ecosystem services assessment.

\section{References}

Boyd J., Banzhaf S., 2007, What are ecosystem services? The need for standardized environmental accounting units, Ecological Economics, no. 63, pp. 616-626.

Brown G., Montag J.M., Lyon K., 2012, Public participation GIS: A method for identifying ecosystem services, Society \& Natural Resources, no. 25(7), pp. 633-651. 
Carpenter S.R., Mooney H.A., Agard J., Capistrano D., Defries R.S., Diaz S., 2009, Science for managing ecosystem services: Beyond Millennium Ecosystem Assessment, Proceedings of the National Academy of Sciences USA, 106 (5), pp. 1305-1312.

Chee Y.E., 2004, An ecological perspective on the valuation of ecosystem services, Biological Conservation, no. 120, pp. 549-565.

Clark W.C., Dickson N.M., 2003, Sustainability science: The emerging research programme, Proceedings of the National Academy of Sciences USA, 100 (14), pp. 8059-8061.

Costanza R., D’Arge R., De Groot R.S., Farberk S., GrassoM., Hannon B., Limburg K., Naeem S., O’Neill R.V., Paruelo J., Raskin R.G., Suttonk P., van den Belt M., 1997, The value of the world's ecosystem services and natural capital, Nature, no. 387, pp. 253-260.

De Groot R.S., Wilson M.A., Boumans R.M.J., 2002, A typology for the classification, description and valuation of ecosystem functions, goods and services, Ecological Economics, no. 41, pp. 393-408.

European Commission, 1997, Compendium of European Planning Systems, Regional Development Studies Report, 28, Office for Official Publications of the European Communities, Luxemburg

Farber S., Costanza R., Childers D.L., Erikson J., Gross K., Grove M., Kahn J., Princetl S., Troy A., Warren P., Wilson M., 2006, Linking ecology and economics for ecosystem management options, Bioscience, no. 56, pp. 121-133.

Geneletti D., 2012, Integrating Ecosystem Services in Land Use Planning: Concepts ad Applications, Working Papers, 54, Center for International Development at Harvard University, www.hks. harvard.edu/var/ezp_site/storage/fckeditor/file/pdfs/centers-programs/centers/cid/publications/ student-fellows/wp/054.pdf (23.09.2013).

Haines-Young R., Potchin M., 2011, Common International Classification of Ecosystem Services (CICES): 2011 Update, [Electronic document]. http://unstats.un.org/unsd/envaccounting/seeaLES/egm/Issue8a.pdf [access date: 30-09-2012]

Jenkins W.A., Murray B.C., Kramer, R.A., Faulkner S.P., 2010, Valuing eco-system services from wetlands restoration in the Mississippi Alluvial Valley, Ecological Economics, no. 69, pp. 1051-1061.

Kowalczyk M., Kulczyk S., 2012, Ecosystem services in tourism research; case study of aquatic recreation, Economy and Environment, no. 2 (42), pp. 200-208.

Kremen C., 2005, Managing ecosystem services: what do we need to know about their ecology?, Ecology Letters, no. 8, pp. 468-479.

Millennium Ecosystem Assessment, 2005, Ecosystems and Human Well - being: Synthesis. Island Press, Washington D.C.

Oxford Dictionary, http://www.oxforddictionaries.com (access date: 26.11.2013).

Planowanie Przestrzenne w Gminach (PP-1), Główny Urząd Statystyczny, 2013.

Tallis H., Polasky S., 2009, Mapping and valuing ecosystem services an approach for conservation and natural-resource management, Annals of the New York Academy of Sciences ,1162, pp. 265-283.

Wallace K.J., 2007, Classification of ecosystem services: Problems and solutions, Biological Conservation, no. 139, pp. 235-245.

Wolak R., Kalafatis S., Harris P., 1998, An Investigation Into Four Characteristics of Services, Journal of Empirical Generalisations in Marketing Science, vol. 3, pp. 22-43 http://members.byronsharp. com/empgens/emp1.pdf. 


\section{Legal Acts:}

Directive 2001/42/EC of the European Parliament and of the Council of 27 June 2001 on the assessment of the effects of certain plans and programmes on the environment.

Rozporządzenie Ministra Infrastruktury z dnia 26 sierpnia 2003 r. w sprawie wymaganego zakresu projektu miejscowego planu zagospodarowania przestrzennego (Dz. U. $2003 \mathrm{Nr} 164$ poz. 1587)

Rozporządzenie Ministra Środowiska z dnia 9 września 2002 r. w sprawie opracowań ekofizjograficznych (Dz. U. 2002 Nr 155 poz. 1298).

Ustawa o planowaniu i zagospodarowaniu przestrzennym z dnia 27 marca 2003 r. (Dz. U. Nr 80, poz. 717).

Ustawa o zagospodarowaniu przestrzennym z dnia 7 lipca 1994 r. (Dz. U. Nr 89, poz.415).

Ustawa z dnia 27 kwietnia 2001 r. Prawo ochrony środowiska (Dz. U. $2001 \mathrm{Nr} 62$ poz. 627).

Ustawa z dnia 3 października 2008 r. o udostępnianiu informacji o środowisku i jego ochronie, udziale społeczeństwa w ochronie środowiska oraz o ocenach oddziaływania na środowisko (Dz. U. 2008 nr 199 poz. 1227). 